
\title{
R Resercrch Suare \\ The Effect of Urban Redevelopment Induced Displacement and Resettlement on Social Capital in Ethiopia
}

Endalew Terefe Alene ( $\square$ eterefe2020@gmail.com )

University of Gondar

\section{Research Article}

Keywords: Social capital, Urban Redevelopment Induced Displacement, Gondar, Resettlement

Posted Date: October 26th, 2021

DOI: https://doi.org/10.21203/rs.3.rs-1020191/v1

License: (c) (i) This work is licensed under a Creative Commons Attribution 4.0 International License.

Read Full License 


\section{Abstract}

City transformation in Sub-Saharan Africa by its nature require massive physical space to accommodate urban development. Accordingly, urban redevelopment program is taken place in many old inner-city settlements to increase the supply of land for commercial and residential development. To this end, these practice often lead to displacement of residents from their original location which in turn affects their livelihoods. The trend and situation of urban development program in Ethiopia and Gondar city is no exception. To this end, this paper assess the effects of urban redevelopment induced displacement and resettlement on social capital in Gondar city. To achieve the objective of the research, a questionnaire survey covering 147 displaced households with interview and field observation was carried out. The findings highlight that, though resettlement has positive effects to the people, the displaced households in Gondar city were lost their neighborhood ties and social networks such as Idir, Equb, Mahiber and Senbetie in their new location. In addition, they also endures several adverse impacts on their basic infrastructure facilities. Therefore, government should understand the social capital impacts in both pre and post relocation phases to improve and strength the displaced households social networks and relationships throughout the entire resettlement process.

\section{Introduction}

Urbanization is a necessary process for the development of an economy of a nation. However, as the urbanization process continues to accelerate, the demand for land by capital, technology, and other production factors is increasing, making limited urban land resources scarcer (Jin, Chin, Yu, \& Zhang, 2020). Therefore, on the one hand, cities will inevitably acquire land from rural areas. On the other hand, the city must redevelop its outdated areas to make better use of its existing land. As a matter of fact, urban redevelopment generally leads to the reconstruction of the built environment and the relocation of original residents, which leads to substantial weakening of existing neighborhood attachment and neighborly relationships (Julianna, 2014). Extensive evidences shows that, in several cities of Ethiopia urban redevelopment projects are increasingly implemented to achieve multiple and varied goals including eradicating unplanned settlements, improving the quality of urban housing stocks, and more generally improving the urban living environments (Abebe, 2013). In this context, these projects will certainly improve the lives of many people, however the "involuntary displacements caused by such projects also creates major impositions on some population segments", as stated by Cernea (1997). Moreover, the non-material impacts may be even greater, including human rights violations, deep fractures in social structures, networks and ties, threats to cultural identity and health, and destruction of social capital (Gebrie, 2016).

So as to assess the effects of urban redevelopment induced displacement on social capital of displaced households, a detailed and regular study at country, city, and neighborhood level is important to provide result-oriented and sustainable support to the affected households (Abebe, 2013; Gebre, 2014; Wayessa, 2020; Woldeyesus, 2017). With reference to this, small number of studies has been carried out in different parts of the country to assess the urban development induced displacement and its impact of the 
livelihood assets of the displaced households. This includes the studies made by Abebe (2013); Ambaye \& Abeliene (2015); Gebre (2014); Gebreegziabher (2014); Gebrie (2016); Teddla (2008); and Woldeyesus (2017) to mention a few. However, these studies discuss effects of urban development induced displacement on livelihood assets. More importantly, these findings suggested that there are various impacts of development induced displacement on the economic, social and psychological impacts which calls for genuine consultation and participation of displaces involving NGOs, Civil societies, human right institutions, judicial reviews of displacement process and closer relocation sites for displaced households. In addition, these studies also provide neither consistent finding nor address the effects of urban development induced displacement in the country. They tried to assess development induced displacement and its impact on relocated households in Ethiopia. So far, to the best of the researcher's knowledge, too limited studies were conducted on the effects of urban redevelopment induced displacement on social capitals of displaced households. To this end, a study conducted by Mekonnen (2019) that assessed development induced displacement of urban dwellers in Addis Ababa: an implication for rebuilding social capital by using mixed research method which includes qualitative and quantitative research approach. This study incorporated only the role of the government to rebuild social capital and factors that affect social capital in development induced displacement areas to explore development induced displacement impact on social capital ignoring the detrimental social effects of urban redevelopment include loss of community cohesion, forced relocation or displacement of original inhabitants, and lower social ties among neighbors which discussed in the literature.

In the same vein, apart from the Ethiopian context, previous studies have been carried out in different parts of the world to assess the effects of urban redevelopment induced displacement on social capitals. However, evidences in developed and developing countries revealed inconclusive findings with regard to the impacts of redevelopment program. Although the impact and magnitude of urban development induced displacement vary from country to country, city to city, and neighborhood to neighborhood, there are many common social asset indicators that considered as development induced displacement impact on social capital in literature of urban development induced displacement. To mention few, dispersion and fragmentation of communities, dismantles patterns of social organization and interpersonal ties and scattering of kinship groups are among others More specifically, loss of existing community-based mutual help and support, loss of customer-seller networks, loss of community-based saving groups. In this context, these social asset indicators were collected from studies made by Bhattacharya, Mal, Tripathy, Mandal, \& Ghosh (2013); Jin et al. (2020); Julianna (2014); Kaviarasu, Dinesh, \& Cruz (2019); Kim, Marcouiller, \& Choi (2019); Ying Liu, Geertman, Oort, \& Lin (2018); Yuqi Liu, Wu, Liu, \& Li (2017); Majrashi (2017); Markoç \& Çinar (2018); Nikuze, Sliuzas, \& Flacke (2020); Shaw \& Saharan (2019); Tran (2015); and Vanclay (2017) through systematic review. Therefore, the above evidences suggests the following reasons why additional research in the area of urban redevelopment induced displacement and resettlement is needed in the context of Ethiopia in general and Gondar city in particular as one of an emerging urban center of the country.

Accordingly, the first reason is urban redevelopment induced displacement have an impact on social assets of the displaced households; even the redevelopment program have positive socio-economic 
benefits for the relocated households in Ethiopia, but the negative impact is still significant and impacts are differ from program to program. If so, the urban redevelopment displacement effect in Gondar city are no exception to this. Secondly, despite the fact that previous empirical studies of different countries have identified the common effects of urban redevelopment displacement on social capital, the influence and magnitude of each effect on the relocated households social capital vary from one area to the other which provide inconsistent findings that cannot be generalized and needs further research. Lastly, in the context of Ethiopia, all existing studies on the impacts of urban redevelopment induced displacement are concentrated on the livelihood assets only in Addis Ababa city and so far no study is conducted particularly in the selected case study area which leads the researcher to conduct this study to fill the gap on the issue specifically concentrated on the social capital and infrastructural challenges.

As a result, against this background, the purpose of this study was to the effect of urban redevelopment induced displacement on social capital in Gondar city of Northwest Ethiopia. The novelty of this paper is that it concentrated on the social assets and infrastructural challenges of the displaced households so as to fill the gap in the urban development induced displacement literature in developing countries unlike the existing studies made by Mekonnen (2019). Most importantly, this paper tried to answer the question of what are the effects of urban redevelopment induced displacement on social capital and what are the major infrastructural challenges that face displaced households from homesteads in Gondar city using quantitative and qualitative data with field observation. This paper proceeds as follows; first, it discusses review of related literature. Second, it describes the methodology of the study. Third, it discusses and presents the quantitative and qualitative data and finally, it present conclusion of the study.

\section{Literature Review: Concepts of Urban redevelopment and social capital}

Urban redevelopment is a land redevelopment process which helps to regenerate an aging area. This process often involves demolition of old building structures relocation of businesses and people. It also brings new urban designs and new concepts to the target redevelopment zones; it redefines what "Up-tostandard" means to both the general public and the people living in the redevelopment zones (Julianna, 2014).

Urban redevelopment also helps to maintain a suitable balance among the social, environmental, economic and cultural aspects to make sure all these dimensions are working harmoniously to enhance the sustainability of the redevelopment zones. Every move made during the redevelopment process of a zone brings about positive and negative impacts on the people, environment, economy and existing social linkage (Julianna, 2014).

Urban redevelopment induced displacement is not just about the loss of households or land, its having varied dimensions. As the policy makers often pay less attention to the community profile and related needs of the community life of the population, the uprooting and planting of the life again in new place often ends up unforeseen losses. The losses includes in the areas of socio-economic and cultural living. Its effects on the livelihood and infrastructure aspects of the people were not effectively addressed by the government or corporate sector. However, in relation with the broken social ties and cultural practices, this 
policies are deaf and dumb to meet the intangible losses. It's a stunning fact from many of the studies and experiences that the loss of social capital and social cohesion is common in redevelopment displacement (Nikuze, Sliuzas, \& Flacke, 2020).

According to Yuqi Liu et al. (2017) urban redevelopment generally leads to the reconstruction of the built environment and the relocation of original residents, which leads to substantial weakening of existing neighborhood attachment and neighborly relationships. For example, a survey carried out in Sarigol, Istanbul, Turkey indicated that those forced to relocate due to urban regeneration projects had little attachment to their new neighborhoods and suffered from the loss of their original social ties (Markoç \& Çinar, 2018). Another survey conducted in Guangzhou, China showed that those who moved back to their previous neighborhoods after redevelopment suffered from a sense of disorientation and isolation (Yuqi Liu et al., 2017). Moreover, the detrimental effect of urban redevelopment appears to vary among different social groups in low-income neighborhoods; after the large-scale redevelopment, resettled residents are more likely than newly arrived residents to be subject to social disturbance (Nikuze et al., 2020). While resettled residents tend to have little contact with new residents as they still rely on former neighborly relations for social support, new residents rarely seek social support through either current or former neighborly relationships (Ambaye \& Abeliene, 2015).

\section{The effect of urban redevelopment induced displacement on social capital in Ethiopia}

Social organizations are established by community on the basis of common norms and values for a common purpose. These community organization have long history and practice regularly in Ethiopia to increase social networks and solve societal problems. Some of the community organization that regularly practiced are Iddir, Ekub, Senbetie, Mahber and others. The presence and participation of individuals in these community organizations are essential to strengthen and build social capital (Ejigu \& Abraha, 2018).

Extensive evidences revealed that in developing countries the displacement and resettlement of people and business form their original location is mainly through urban redevelopment. In this sense, the displaced communities are lost their locational advantages of accessing social services like education, health services, electricity, water and transportation that linked with the original settlement (Admassu, 2018). On the other context, development induced displacement in general have impacted displaced community to landlessness, homelessness, joblessness, marginalization, food insecurity, increased morbidity and mortality, loss of access to common property and social disintegration (M. M. Cernea, 1995).

Equivalently with other livelihood assets, social capital has affected by development induced displacement. To this end, one of the predominant results of displacement and relocation is the disintegration of the existing social bounds of the community. Ejigu \& Abraha (2018) observed that relocation of communities' form their original place in Addis Ababa was done based on the authority's 
willingness only through random patterns without considering the social issues of a neighborhood. They further stated that such resettlement scheme was disintegration of basic social institution and neighborhood ties. Moreover, previous researchers have found that social capital has a great contributions to make individual livelihood safe through increases the exchange of information, material, goods and services among the people. On the other context, a study by Abebe (2013); Gebrie (2016); Hosaena (2020); Hussen \& Kibret (2018); and Tarekegn (2013) conducted in Addis Ababa reported that urban development induced displacement has often brought breakup of the existing neighborhood ties following displacement from their original place. In addition, a study conducted by Robinson (2003) pointed out that displacement may destroy existing patterns of social networks and togetherness due to people are separated. On the contrary, Nikuze, Sliuzas, Flacke, \& Maarseveen (2019) reported that social disintegration can also occurred even when the affected people are still living in the same neighborhood.

It is obvious that urban centers need well organized and planned system of different infrastructures and social services to serve the nearby and surrounding communities. As a result, the communities regularly need infrastructures such as education, health services, electricity, water, transport and so on. On the other side, urban redevelopment have an impact on the infrastructure accessibility and occupational change of the displaced people. Accordingly, Ambaye \& Abeliene (2015); Ejigu \& Abraha (2018); Gebre (2014); Hosaena (2020) and Nikuze et al. (2019) pointed out access to transport, education, water, health services and sewerage system are serious challenges in the new settlement area.

\section{Materials And Methods}

\section{Study Area}

The study was conducted in Ethiopia by taking Gondar city as a case study. The city is one of the regiopolitan city of Amhara regional state of Ethiopia. The city absolute geographical location is between $12^{\circ} 36^{\prime}$ North latitude and $37^{\circ} 28^{\prime}$ East longitude and has an average elevation of $2201 \mathrm{~m}$ above the sea level. Topographically, the city to large extent lie on a semi-flat plain and also surrounded on three sides by a crown of 3,000 meter high mountains. The city is one of the oldest and currently the fastest growing urban center in Ethiopia. According to the Central Statistical Agency (CSA), the current number of population of the city is projected to be 475,452 in 2019 (Fig. 1).

\section{Research Design and Sample size determination}

It is obvious that the researcher should choose the best research design based on the need and purpose of the study to achieve research objectives (Cresswell, 2014). Accordingly, by considering purpose of the research, method of data collection, time dimension, and research approach, a researcher could choose its best fit research design (Bhattacherjee, 2012). As a result, the current study employed descriptive cross-sectional survey research design with primary and secondary data. The primary data were collected by structured questionnaire; and secondary data were collected from the literature review and other 
secondary data sources. Furthermore, a two-stage random sampling technique was used to select sample respondents in the study area. In the first stage, Azezzo-Tseda sub-city was purposively selected to conduct the study since this sub-city is an area of redevelopment project is practiced and a large number of people are displaced due to the redevelopment project. The number of displaced people in the sub-city was 530. In the second stage, the total sample size was determined using formula provided by (C.R. Kothari, 2004) to determine the required sample size at $95 \%$ confidence level and with $0.03 \%$ level of error (Eq. 1):

$$
\mathrm{n}=\frac{Z^{2} p x q x N}{e^{2} x(N-1)+Z^{2} p x q}
$$

Where $\mathrm{N}=$ Size of total population $=530 ; \mathrm{n}=$ size of sample; $\mathrm{e}=$ acceptable error $(0.05) ; \mathrm{z}=$ standard variant a given confidence level (1.96) $95 \%$ confidence; $p=(0.05)$ population proportion; and $q=1-p(1-$ $0.05=0.95)$. Therefore, using the above formula the calculated number of sample size is 147 . Besides, respondents were randomly selected from the sub-city based on the sub-city roster used as a sampling frame.

\section{Data sources and Methodology}

This study was applied mixed research technique. Accordingly, a structured questionnaire was used to collect quantitative data from 147 displaced households. In the other side, for qualitative method, semistructured interview were conducted to collect data. Semi-structured interviews were carried out with five experts (surveyor, sub-city manager, urban planner, land administration, micro and small enterprise) and two (male and female) affected households in the sub-city administration who were deliberately chosen because it was believed that they had good knowledge in the redevelopment program effects and ability to articulate the effects of redevelopment program on resettled households, particularly on infrastructural challenges, occupational and neighborhood changes in the sub-city. Descriptive statistical methods for quantitative data such as frequencies and percentages were used to summarize the information on respondents' responses, whereas the interviews were analyzed using narrative analysis techniques. Moreover, Observation was conducted in order to complement information obtained from household survey and key informant interviews.

\section{Results And Discussions}

\section{Socio-demographic characteristics of sample respondents}

The survey was distributed 147 questionnaires in the sub-city and all respondents returned a completed questionnaire (100\% response rate). Accordingly, as indicated in Table 1 data were collected from 147 displaced households of which $49 \%$ were females, $62.6 \%$ were married with $61.2 \%$ have four or fewer family members, $84.4 \%$ were aged from $30-65$ years, and $38.1 \%$ have a reading and writing skill only. 
Table 1

Socio-demographic characteristics of sample respondents ( $N=147)$

\begin{tabular}{|c|c|c|}
\hline Socio-demographic Variables & Specific indicators & Percentage \\
\hline \multirow[t]{2}{*}{ Gender } & Male & 51 \\
\hline & Female & 49 \\
\hline \multirow[t]{3}{*}{ Age (in years) } & $18-29$ & 5.4 \\
\hline & $30-65$ & 84.4 \\
\hline & $65+$ & 10.2 \\
\hline \multirow[t]{5}{*}{ Educational level } & Unable to read and write & 26.5 \\
\hline & Reading and writing skill only & 38.1 \\
\hline & Elementary school (1-8 grade) & 12.2 \\
\hline & High school (9-12 grade) & 17.7 \\
\hline & College and above & 5.4 \\
\hline \multirow[t]{4}{*}{ Marital status } & Married & 62.6 \\
\hline & Single (not married) & 14.3 \\
\hline & Divorced & 8.8 \\
\hline & Widowed & 14.3 \\
\hline \multirow[t]{3}{*}{ Family size } & $1-4$ & 61.2 \\
\hline & $5-8$ & 28.6 \\
\hline & $8+$ & 10.2 \\
\hline
\end{tabular}

\section{Reasons of Displacement}

responses obtained from the key informants revealed that the main reason for the resettlement of households were due to infrastructure and market center development. For example, the sub-city manager said that "we resettled the households with their consent for the sake of infrastructure development such as road, solid and liquid waste disposal site and education center and for market center development in the sub-city kebeles." Another elder interviewee (male, 65 years aged) responded as follows

... We are not happy to resettle into the new settlement site by the urban redevelopment program specifically for infrastructure and market center development, though the aim of the program is to improve many people's lives, provide employment, and supply better services. 
In the same vein, responses obtained from the survey indicated similar result with the interview. More importantly, among the displaced households who filled in the questionnaire, 81 of them responded that the reason for displacement was for market center development (Table 2). Furthermore, the result also confirmed by field observation. This finding is consistent with the findings of Aboda, Mugagga, Byakagaba, \& Nabanoga (2019) who reported that the cause of displacement in urban area is due to large scale development projects such as urban development and transportation projects. Moreover, this study finding is also consistent with the findings of (Vanclay, 2017).

Table 2

Causes of Displacement $(\mathrm{N}=147)$

\begin{tabular}{|ll|}
\hline Causes for displacement & Percentage \\
\hline Infrastructure development & 44.9 \\
\hline Market center development & 55.1 \\
\hline Source: survey result, 2021 & \\
\hline
\end{tabular}

\section{Infrastructure Challenges}

It is obvious that urban redevelopment program always leads to displacement of existing residents. If so, provision of basic infrastructure services are mandatory for the displaced peoples. However, in many subSaharan Africa countries resettlement process was implemented without the development of infrastructures (Gebreegziabher, 2014). Accordingly, responses obtained from the majority $(78.9 \%, 71.6 \%$, $71.4 \%$, and $82.4 \%$ ) study participants respectively revealed that health services, water supply, education services, and transportation services were far in distance from their new location as compared to the previous settlement area (Table 3). This implies that displaced households are encountered a problem accessing of basic infrastructure facilities in their new location. Similarly, responses obtained from key informants was confirmed the survey result. For example, the displaced women (60 years old) said that "there was a huge difference between health and education services in my previous and current settlement. I cannot access hospital in a short distance at the new residence, but previously my home is at the inner city and I can access hospital and other health station services easily in my residence." On the other context, data about accessibility of education facilities for children of the relocated households revealed that they were encountered shortage of schools for their children in their new residence. This was supported by the following quote of elder male interviewee, age 65. "In my previous residence I can send my children to different schools because we had various options. The schools were also found relatively near to our homes. However, in the new settlement we have very limited options and a few available schools are located at distant areas." It is also confirmed by field observation. In line with this, the current study is consistent with the research findings of (Ambaye \& Abeliene, 2015; Ejigu \& Abraha, 2018; Gebreegziabher, 2014; Hussen \& Kibret, 2018; Nikuze et al., 2019). 
Table 3

Basic infrastructure facilities in the new location

comparing to the previous residence $(\mathrm{N}=147)$

\begin{tabular}{|lll|}
\hline Variable & Distance & Percentage \\
\hline Health care service & Very far & 6.1 \\
\cline { 2 - 3 } Water supply & Far & 78.9 \\
\cline { 2 - 3 } & Near & 15.0 \\
& Very far & 6.8 \\
\cline { 2 - 3 } Education service & Far & 71.6 \\
\cline { 2 - 3 } & Near & 21.6 \\
& Very far & 8.2 \\
\cline { 2 - 3 } & Far & 71.4 \\
\cline { 2 - 3 } Transportation service & Near & 20.4 \\
\cline { 2 - 3 } & Very far & 12.2 \\
\cline { 2 - 3 } & Far & 82.4 \\
\cline { 2 - 3 } & Near & 5.4 \\
\hline Source: Survey result, 2021 & \\
\hline
\end{tabular}

\section{Loss of Social Capital}

As it is clearly indicated in the literature, urban redevelopment induced displacement caused destruction of social networks or neighborhood ties of the displaced households. Extensive evidences revealed that neighborhood ties were not take in account by the concerned authorities of the redevelopment program during the process of resettlement (Ambaye \& Abeliene, 2015; Mekonnen, 2019). In this context, responses obtained from survey participants revealed that pervious and long lasting neighborhood ties is completely disintegrated in the new settlement. For example, nearly all of the study participants lost their neighborhood ties due to relocation. In the other side, $95.2 \%$ of participants also lost their social network such as Idir, Equb, Mahiber and Sebete (Table 4). This finding further supported by the responses obtained from key informants. In this regard, a response from 37 years old young man which was taken from the interview supports the above result. "There were so many people around me in the previous residence and I had strong attachment with them. However, during the resettlement all those friends and others whom I know were resettled to different sites. All previous social organizations such as Idir, Equb, Mahiber and Senbete are disintegrated. I found it so difficult to carry out my life without having my previous social networks." Furthermore, a woman with 60 years old responded the relocation program was not separated only our neighbors but also it separated my families. Now it is difficult to live without the family members and I lost different family supports due to the resettlement program. This implies 
that forced displacement breaking up the existing social fabric. It separated and disintegrated communities, destructs patterns of social organization and interpersonal ties; friend and families become disperses as well. Mutual supports with each other as a valuable social capital are destructs. This results also the loss of human, natural, physical and financial livelihood capitals. As many evidences reported that the loss of social capital is not give consideration by any development induced displacement program. If so, social disarticulation has long term impact on the displaced people which need the attention of government before making decision for relocating people from their original location. This finding is consistent with the research findings of (Aboda et al., 2019; Ambaye \& Abeliene, 2015; M. M. Cernea, 2009; Ejigu \& Abraha, 2018; Hussen \& Kibret, 2018; Yuqi Liu et al., 2017; Markoç \& Çinar, 2018; Nikuze et al., 2019).

Table 4

Social network disintegration of the displaced households

\begin{tabular}{|lllll|}
\hline Variables & $\begin{array}{l}\text { Strongly } \\
\text { agree }\end{array}$ & Agree & Disagree & $\begin{array}{l}\text { Strongly } \\
\text { disagree }\end{array}$ \\
\hline Lost neighborhood ties & $\begin{array}{l}132 \\
(89.8 \%)\end{array}$ & $\begin{array}{l}15 \\
(10.2 \%)\end{array}$ & - & - \\
\hline $\begin{array}{l}\text { Lost social networks (Idir, Ekub, Mahiber and } \\
\text { Senbetie) }\end{array}$ & $128(87 \%)$ & $\begin{array}{l}12 \\
(8.2 \%)\end{array}$ & $5(3.4 \%)$ & $2(1.4 \%)$ \\
\hline Source: Survey result, 2021 & & & & \\
\hline
\end{tabular}

\section{Conclusion}

Extensive evidences shows that in the 21st century the spatial extent of urban centers are growing faster than their population with consuming of more land for urban development. As a result, to acquire more land for urban development, many urban centers are implementing different urban redevelopment program on outdated areas to make better use its existing land as well as accessing of more land. With reference to this, urban redevelopment program in cities of fast growing countries in Sub-Saharan Africa is characterized by displacing of many urban population from their original location. Accordingly, this study has provided insights into the effects of such urban redevelopment induced displacement process on social capitals and infrastructural challenges of affected households in Gondar city, Northwest Ethiopia. In this context, this findings strengthened the arguments that resettlement of population due to urban redevelopment program is a complex process that caused various negative social impact on the affected displaced households. To this end, this study found that the relocated households were lost their social capital due to the urban redevelopment program. Specifically, it breaking up neighborhood ties and social organizations such as Idir, Equb, Mahiber and Senbetie. In addition, they also encountered a problem accessing of basic infrastructure facilities such as health care, water supply, education and road services in their new location.

Social capital which was built for many years in the previous residence is always in relocates heart. Missing this neighborhood ties makes them to consider as they are loneliness and strange. The findings of this study, therefore, suggest that the national government and city administration should consider the 
social network of the households before making decision to displace them and try to resettle them together per their previous relationships. In the other side, providing basic infrastructure services to the displaced households is the responsibility of the authorized body. However, as evidences shows that most of the resettlement program is implemented without providing of basic infrastructures services such as health care services, water supply, education services, road services and so on. Most relocation sites are found very far from the center of the city which needs travelling of long distance to access the basic infrastructure services. To this end, the concerned authorized bodies should construct and fulfilled those basic infrastructures to the displaced household before they decide to resettle the households from their original location. It also needs the collaboration of stakeholders and developers to provide infrastructures to the affected households.

\section{Declarations}

\section{Authors' contributions}

I have carried out all the whole works of the study. I designed the study research design, carried out the field work, document analysis, literature work, manuscript draft and editorial. The author, Endalew Terefe, personally undertook this study. The author also read and approved the final manuscript.

\section{Author details}

Department of Development and Environmental Management Studies, University of Gondar, P.O. Box 196, Gondar, Ethiopia.

\section{Acknowledgements}

I would like to thank the research participants who are lived in Azezzo-Tseda-sub city for their willingness to give information to the research question.

\section{Competing interests}

The author declare that there is no competing interests.

\section{Availability of the data and materials}

The data is included in the manuscript. The quantitative data analyzed in the current study are not publicly available due to confidentiality reasons, but are available from the corresponding author on reasonable request.

\section{Ethics approval and consent to participate}

Not applicable since this research did not involve human subject.

\section{Consent for publication}


I have agreed to submit for Journal of Global Social Welfare and approved the manuscript for submission.

\section{Funding}

This study was conducted by the Author finance only. There is no any financial support from any organization.

\section{References}

Abebe, G. (2013). Implications of Urban Development-Induced Resettlement on Poor Households in Addis Ababa. Ghana Journal of Geography, 5(2), 32-50.

Aboda, C., Mugagga, F., Byakagaba, P., \& Nabanoga, G. (2019). Development Induced Displacement; A Review of Risks Faced by Communities in Developing Countries. Sociology and Anthropology, 7(2), 100110. https://doi.org/10.13189/sa.2019.070205

Admassu, R. (2018). Urban Redevelopment Challenges in Addis Ababa City Administration: The Case of Kirkos Sub-city. A thesis submitted to the Department of Public Administration and Development Management of Addis Ababa University in partial fulfillment of the requirements for the Degree of Masters in Public Management and Policy (MPMP), Addis Ababa, Ethiopia.

Ambaye, G., \& Abeliene, A. (2015). Development-Induced Displacement and Its Impacts on the Livelihoods of Poor Urban Households in Bahir Dar, North Western Ethiopia. AHMR, 1(3), 310-331.

Bhattacharya, P., Mal, S., Tripathy, S., Mandal, S., \& Ghosh, B. (2013). Development-Induced Displacement and Human Development through Industrialisation in India. African Journal of Geo-Science Research, 1(3), 1-5.

Bhattacherjee, A. (2012). Social Science Research: Principles, Methods, and Practices (Second Edi). Florida, USA: Creative Commons Attribution-NonCommercial-ShareAlike 3.0 Unported License.

Cernea, M. (1997). The Risks and Reconstruction Model for Resettling Displaced Populations. World Development, 25(10), 1569-1587. https://doi.org/10.2307/4409836

Cernea, M. M. (1995). Understanding and Preventing Impoverishment from Displacement: Reflections on the State of Knowledge. Journal of Refugee Studies, 8(3).

Cernea, M. M. (2009). Introduction: Resettlement - An Enduring Issue in Development. The Asia Pacific Journal of Anthropology, 10(4), 263-265. https://doi.org/10.1080/14442210903079756

Cresswell, J. W. (2014). Research Design: Qualitative, Quantitative and Mixed Methods Approaches (Fourth Edi; V. Knight, J. Young, \& K. Koscielak, Eds.). California, USA: SAGE Publications, Inc. 2455 Teller Road Thousand Oaks, California 91320. 
Ejigu, B., \& Abraha, G. (2018). Effects of Urban Redevelopment Project on the Livelihood of Resettled Households: The Case of Addis Ababa Senga Tera Fird Bet Project-I, Lideta Sub-City. Developing Country Studies, 8(2), 56-68.

Gebre, H. A. (2014). The Impact of Urban Redevelopment-Induced Relocation on Relocatees ' Livelihood Asset and Activity in Addis Ababa: The Case of People Relocated Arat Kilo Area. Asian Journal of Humanities and Social Studies, 02(01), 43-50.

Gebreegziabher, T. T. (2014). The Effect of Development Induced Displacement on Relocated Household: The Case of Addis Ababa. A Thesis submitted in partial fulfillment of the requirements for obtaining the degree of Master of Arts in Development Studies, International Institute of Social Studies

Gebrie, E. (2016). Impacts of Urban Renewal Induced Displacement and Resettlement on the Economic and Social Life of Displaced People: The Case of YekaAyat 2 Condominium, Addis Ababa, Ethiopia. A Thesis Submitted to the Department of Geography and Environmental Studies Presented in Partial Fulfillment of the Requirements for the Degree of Master of Arts in Geography and Environmental Studies (Population, Resources and Development), Addis Ababa University.

Hosaena, S. (2020). The Socio-Economic Impact of Development Induced Displacement: The Case of Kirkose Sub City, Wereda 08, Hilton Hotel Area. A Thesis Submitted to St.Marys University, School of Graduate Studies in Partial Fulfillment of the requirements for the Degree of Masters of Social Work, Addis Ababa, Ethiopia.

Hussen, A. K., \& Kibret, B. T. (2018). Perceived Effects of Development-Induced Displacement on LowIncome Households in Addis Ababa. Scholarly Journal of Psychology and Behavioral Sciences, 1(2), 3445. https://doi.org/10.32474/SJPBS.2018.01.000108

Jin, X., Chin, T., Yu, J., \& Zhang, Y. (2020). How Government's Policy Implementation Methods Influence Urban Villagers' Acceptance of Urban Revitalization Programs: Evidence from China. Land (MDPI), 9(77), $1-19$.

Julianna, O. C. L. (2014). The Effect of Urban Redevelopment on the Community: A Case Study in Kwun Tong. A Thesis Submitted in partial fulfillment of the requirements for the degree of Master of Housing Management, The University of Hong Kong.

Kaviarasu, S. J., Dinesh, J. J., \& Cruz, M. T. (2019). Problem of Development Induced Displacement and its Suggested Solutions - In Tamil Nadu. International Journal of Innovative Studies in Sociology and Humanities, 4(1), 74-80.

Kim, H., Marcouiller, D. W., \& Choi, Y. (2019). Urban Redevelopment with Justice Implications: The Role of Social Justice and Social Capital in Residential Relocation Decisions. Urban Affairs Review, 55(1), 288320. https://doi.org/10.1177/1078087418759605 
Liu, Ying, Geertman, S., Oort, frank van, \& Lin, Y. (2018). Making the 'Invisible' Visible: Redevelopmentinduced Displacement of Migrants in Shenzhen, China. International Journal of Urban and Regional Research, 21(10), 483-499. https://doi.org/10.1111/1468-2427.12646

Liu, Yuqi, Wu, F., Liu, Y., \& Li, Z. (2017). Changing neighbourhood cohesion under the impact of urban redevelopment: a case study of Guangzhou, China. Urban Geography, 38(2), 266-290.

https://doi.org/10.1080/02723638.2016.1152842

Majrashi, A. A. (2017). Development-Induced Displacement of Informal Settlements in Makkah, Saudi Arabia. A thesis submitted in fulfilment of the requirements for the award of the degree of Doctor of Philosophy (Urban and Regional Planning) for Faculty of Built Environment Universiti Teknologi Malaysia.

Markoç, I., \& Çinar, C. (2018). Loss of Social Belonging, Displacement and Social Exclusion in the Neighborhood : Urban Redevelopment in Sarigol, Istanbul, Turkey. Megaron, 13(2), 169-181. https://doi.org/10.5505/MEGARON.2017.97658

Mekonnen, A. (2019). Development Induced Displacement of Urban Dwellers in Addis Ababa: An Implication for Rebuilding Social Capital. A Thesis Submitted to College of Business and Economics, Department of Public Administration and Development Management Presented in Partial Fulfillment of Requirements for the Degree of Masters in Public Management and Policy, Addis Ababa University, Eth.

Nikuze, A., Sliuzas, R., \& Flacke, J. (2020). From Closed to Claimed Spaces for Participation: Contestation in Urban Redevelopment Induced- Displacements and Resettlement in Kigali, Rwanda. Land (MDPI), 9(212), 1-19.

Nikuze, A., Sliuzas, R., Flacke, J., \& Maarseveen, M. Van. (2019). Livelihood impacts of displacement and resettlement on informal households - A case study from Kigali, Rwanda. Habitat International, 86(September 2018), 38-47. https://doi.org/10.1016/j.habitatint.2019.02.006

Robinson, W. C. (2003). Risks and Rights: The Causes, Consequences, and Challenges of DevelopmentInduced Displacement. Washington DC, USA.

Shaw, A., \& Saharan, T. (2019). Urban development-induced displacement and quality of life in Kolkata. International Institute for Environment and Development (IIED), 31(2), 2019.

https://doi.org/10.1177/0956247818816891

Tarekegn, F. (2013). The Impact of Development Induced Displacement on Social Capital in Addis Ababa: An Implication for Rebuilding Social Capital. A thesis submitted to Addis Ababa University, School of Social Work in partial fulfillments of the requirement for the degree of Master in Social Work (MSW), Addis Ababa, Ethiopia. 
Teddla, F. R. (2008). Urban Redevelopment and Displacement in Arada Sub-City of Addis Ababa, Ethiopia. Mini-thesis Submitted in Partial Fulfilment of the Requirements for the MA Degree in Administration. for The Institute of Social Development, Faculty of Arts University of the Western Cape.

Tran, T. A. (2015). The role of social capital and community ties in rebuilding livelihoods of displaced households in peri-urban areas of Ho Chi Minh City. lowa State University Capstones, Theses and Dissertations.

Vanclay, F. (2017). Project-induced displacement and resettlement: from impoverishment risks to an opportunity for development? Impact Assessment and Project Appraisal, 1-20. https://doi.org/10.1080/14615517.2017.1278671

Wayessa, B. S. (2020). ' They deceived us ': Narratives of Addis Ababa development-induced displaced peasants. International Journal of Sociology and Anthropology, 12(September), 67-75.

https://doi.org/10.5897//JSA2020.0862

Woldeyesus, A. H. (2017). The Impact of Basha Wolde Chilot's Relocation Programme on Assets Associated with Housing. Research and Perspectives on Development Practice Series, (20). Dublin, Ireland: Kimmage Development Studies Centre.

\section{Figures}




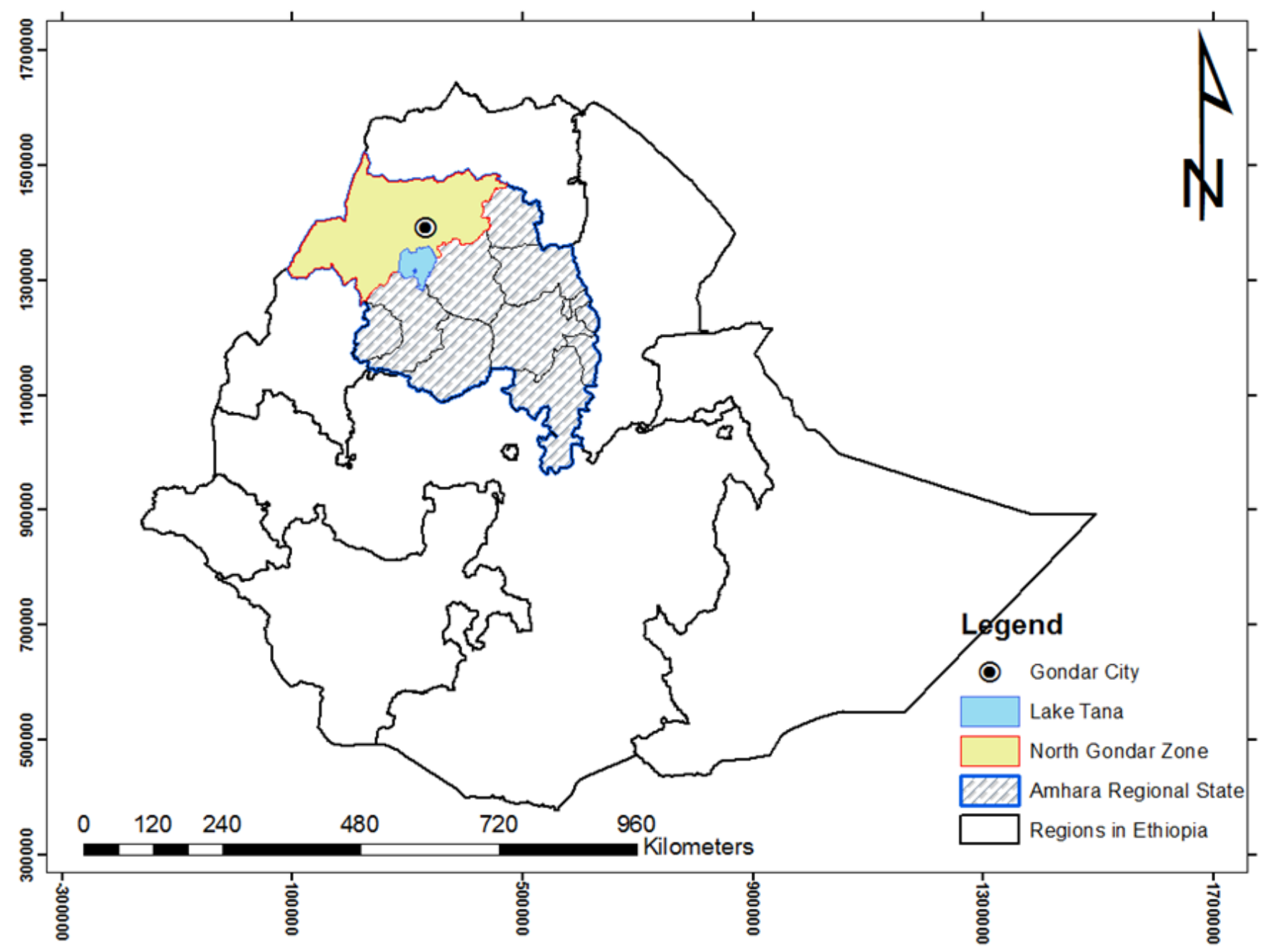

Figure 1

Location of the study area 